\title{
Uzaktan Çalışanlar İçin İnsan Kaynakları Yönetimi
}

\section{Dr. Demet Özcan ${ }^{1 *}$}

Geliș tarihi: 24.12.2019

Kabul tarihi: 09.01.2020

\section{Atıf bilgisi:}

IBAD Sosyal Bilimler Dergisi

Sayı: $6 \quad$ Sayfa: 204-220

Yıl: 2020 Dönem: Kış

This article was checked by iThenticate. Similarity Index $6 \%$

Bu makalede araștırma ve yayın etiğine uyulmuştur.

1 Istanbul Gelisim Üniversitesi, Türkiye, xdemety@yahoo.com,

ORCID ID 0000-0002-3142-2818

\section{ÖZ}

$\mathrm{Bu}$ çalıșmanın temel amacı uzaktan çalıșanların ve ofis çalıșanlarının insan kaynakları yönetimi ve birim yöneticilerinden beklentilerini tespit etmek ve önerilerini ortaya koymaktır. 21 derinlemesine görüşme ile elde edilen verilerin gömülü teori ile analiz edilmesi sonucu, bu beklenti ve öneriler uzaktan çalışma sistemine geçilmeden önce beklenilenler ve uzaktan çalışma sistemine geçildikten sonra bu çalışma sürecindeki beklentiler olarak 2 temel tema altında tanımlanmıştır. Katılımcıların beklentilerine ve önerilerine yönelik detaylı tanımları, temel temaların altında kodlanmıs ve kavramsal çerçeve geliștirilerek öneriler sunulmuștur. Araştırma bulgularının; insan kaynakları yöneticilerinin başarılı bir uzaktan çalışma programı uygulayabilmeleri için yönlendirici olması ve bu yeni çalışma şekline geçilmeden önce ve sonra neyin uygulanılmasının beklendiği ve nasıl uygulanmasının beklenildiğine dair geri bildirim vermesi adına uzaktan çalışanların deneyimleri ve yaşadıkları sıkıntılar ile ilgili derin anlayışı aktarması beklenmektedir.

Anahtar Kelimeler: Uzaktan Çalışma, Gömülü Teori, Uzaktan Çalışma Şekli Konusunda İnsan Kaynakları Yönetimi İçin Öneriler.

\section{* Sorumlu yazar}




\section{Human Resources Management For Teleworkers}

\section{Dr. Demet Özcan ${ }^{1 *}$}

First received: 24.12 .2019

Accepted: 09.01.2020

\section{Citation:}

IBAD Journal of Social Sciences

Issue: 6

Pages: 204-220

Year: 2020

Session: Winter

This article was checked by iThenticate. Similarity Index 6\%

1 Istanbul Gelisim University, Turkey, xdemety@yahoo.com,

ORCID ID 0000-0002-3142-2818

* Corresponding Author

\begin{abstract}
The objective of this paper is to explore the suggestions and expectations of telecommuters and non-telecommuters for human resources management and other leaders. Analysing data from 21 in-depth qualitative interviews according to grounded theory, 2 main themes are identified as: expectations before the initiation of telecommuting and expectations after the initiation of telecommuting. Respondents' intimate and detailed descriptions of their expectations as telecommuters are coded under the main themes and the conceptual model is developed and suggestions are presented. The findings of the study are expected to be a guide for human resources management to apply successful teleworking programs and to give a deep understanding of the experiences, challenges and needs of telecommuters so as to give feedback about what to do and how to do the implementions both before and after the adoption of this new way of working.
\end{abstract}

Keywords: Telecommuting, Grounded Theory, Suggestions for Human Resources Management for Teleworking. 


\section{INTRODUCTION}

Telecommuting has risen as a new way of working together with the rise of the digital transformation and communication technologies. Popular "futurologists" writing in this context equated the widespread mass adaption of telework in the future with the end of the modern hierarchal industrial organization. According to Huws, the "electronic home worker is a highly charged and powerful symbol that promises full participation in the international traffic of ideas and information" (Keating \& Broek, 2007, p.79). "Worldwide, numbers of teleworkers range from 8.5 million in 1995 to over a 100 million in 2008" (Coenen \& Kok, 2014, p.564) and the huge growth potential of telework has effected human resources (HR) processes and applications seriously. Therefore, in this study; in order to make a contribution to the development of human resources functions, applications and procedures for telecommuting, the expectations and suggestions of telecommuters and non-telecommuters are anaylsed, theoretically framed and presented to serve as a guide to appliers in order to develop procedures, tools, agreements, collective agreements and protocols for the telecommuters and their managers.

\section{AIMS of THE STUDY}

The aim of this grounded theory study is to develop a theoretical model that explains the expectations of telecommuters and suggestions of the non-telecommuters for human resources management (HRM), that will make them desire telecommuting. Telecommuting is a new way of working, so with the study it is aimed to provide the theoretical framework for human resources management to understand telecommuters and their expectations better and offer practical suggestions for better procedures and best practices of telecommuting. The suggestions provided by the study are generated from the experiences of the telecommuters in order to show the ways to avoid the risks of telecommuting and to utmostly benefit from the advantages of telecommuting by a qualitative study. The interviews with the teleworkers and non-teleworkers are thorougly analysed according to grounded theory. The main topics of the expectations are presented to make it possible for the appliers to develop specific tools, procedures and best pratices according to the expectations of teleworkers from their managers.

\section{REVIEW of LITERATURE}

Fast growing digitalization has made teleworking a rising working model. In the literature many advantages of teleworking are underlined. But, "despite several decades of research on the benefits of telework, it has not been adopted on the scale anticipated by scholars. In fact, data from academic research, census reports and think-tank reports alike all show the average frequency of telework by organizational employees to be somewhere between 2.2 and 12 percent." (Martin \& MacDonnell, 2012, p.603) "According to Pearlson and Saunders (2001), managers must implement structural changes within the work environment to compensate for the reduced employee-to-employee interaction. Creative attempts at communication, team-building, and employee feedback needs to be addressed in order to reduce any effects of teleworker isolation." (Potts, 2006, p.7) With this study the main goal is to answer the question of how the managers should make these structural changes for this new working environment and show them the ways by exploring the suggestions and expectations of telecommuters and non-telecommuters. "When we seek to describe and understand people's experiences-particularly when we want to develop a deep empathic understanding of what it's like to walk in their shoes or to learn about their experiences from their point of view - qualitative studies reside at the top of the research hierarchy." (Rubin, 2008, p.45) So in order to be able to describe the telecommuters challenges and experiences, qualitative study of grounded theory was applied in this research.

\section{SAMPLE}

The research was conducted with 21 respondents in 2016 and 2017, 16 of which were teleworkers and 5 of which were non-teleworkers knowledged about telecommuting. And they sustained deep and rich data by their detailed explanations of experiences and expectations if they were teleworkers. Snowball sampling method was used for the respondents' selection. Sampling was intentional. "Theoretical or purposeful sampling in grounded theory means that the researcher selects individuals to study based on their contribution to the development of the theory." (Long, 2008, p.18) Also person triangulation was 
applied. "Person triangulation involves collecting data from different types or levels of people with the aim of validating the data through multiple perspectives on the phenomenon." (Polit \& Beck, 2012, p.590) In this way, increasing the validity of the conclusions was provided. So the respondents were chosen consideringly according to their experiences, educational level and from different positions, locations, gender and family status in order to reach a saturated data by discovering the contrasting experiences of teleworkers and ideas of non-teleworkers.

\section{DATA COLLECTION METHODS}

In this exploratory qualitative study, in-depth interviews were used to collect data and the procedures of grounded theory are used to define a theory from the perspectives of the participants about the perception of what HR management should do for an effective teleworking system. In order to collect a multidimensional data set and evaluate the categories with positive and negative aspects, participants were choosen from different professinal groups: different positions, gender, capital structure, locations, marital status, family status (with child or not), telecommuting time (fulltime / parttime), satisfaction status of telecommuting (satisfied /not satisfied). Each interview was audio-taped and transcribed right after the interview. Transcripts were controlled before the analysis in order to ensure the consistency with records. The transcripts were shared with the participants to check for accuracy. In this way, validity and reliability of the study were ensured.

After each interview, similiar and contrasting opinions, experiences and perceptions about telecommuting were cross-examined and codes were controlled. In this way the main categories and themes were structured.

"Transferibility is an important criteria for trustworthiness in qualitative researches. In discussing strategies to support transferability, most writers discuss the need for thick description (Geertz, 1973; Lincoln and Guba, 1985). Thick description refers to rich, thorough descriptive information about the research setting, study participants, and observed transactions and processes. Readers can make good judgements about the proximal similarity of study contexts and their own environments only if researchers provide high-quality descriptive information. As Firestone (1990) noted, thick description is not restricted to prose, as the name implies, but involves all forms of critical information (including demographic information) that helps readers to understand the study's context and participants." (Polit \& Beck, 2010, p.1453-1454) So in order to serve for the transferibility of the study the descriptive information of the data is presented as follows:

Table 1. Demographic characteristics of the respondents

\begin{tabular}{|c|c|}
\hline Characteristic & $\begin{array}{l}\text { Participants } \\
(\mathrm{n}=21)\end{array}$ \\
\hline \multicolumn{2}{|l|}{ Gender } \\
\hline - Man & $13(\% 61,90)$ \\
\hline Telecommuter & $9(\% 69)$ \\
\hline Office Worker & $4(\% 31)$ \\
\hline - Woman & $8(\% 38,10)$ \\
\hline Telecommuter & $7(\% 87,5)$ \\
\hline Office Worker & $1(\% 12,5)$ \\
\hline \multicolumn{2}{|l|}{ Marital Status } \\
\hline - Married & $18(\% 85,71)$ \\
\hline Telecommuter & $13(\% 72,3)$ \\
\hline Office Worker & $5(\% 27,7)$ \\
\hline - Single & $3(\% \quad 14,29)$ \\
\hline Telecommuter & $3(\% 100)$ \\
\hline
\end{tabular}




\begin{tabular}{|l|l|}
\hline Office Worker & $0(\% 0)$ \\
\hline Family Status & \\
\hline • With Kids & $\mathbf{1 7}(\% \mathbf{8 0 , 9 5})$ \\
\hline Telecommuter & $12(\% 70,5)$ \\
\hline Office Worker & $5(\% 29,5)$ \\
\hline - No Kids & $\mathbf{4}(\% \mathbf{1 9 , 0 5})$ \\
\hline Telecommuter & $4(\% 100)$ \\
\hline Office Worker & $0(\% 0)$ \\
\hline
\end{tabular}

From the 21 respondents, 16 were telecommuters, 5 were non-telecommuters, $\% 42,86$ work in foreigncapital firms, $\% 57,14$ work in domestic- capital firms. The respondents were sampled from different locations of Turkey: Istanbul, Izmir, Eskisehir, Mersin, Mardin and Mugla.

In the study teleworking experiences for different positions were analysed: sales, marketing, information technologies, project management, purchasing, product design, top management, licensing. Distribution of the positions of the 21 respondents can be seen in the following table:

Table 2. Respondents' Firms Capital Structure and Positions

\begin{tabular}{|c|c|c|c|c|c|c|}
\hline Code & Work Style & $\begin{array}{l}\text { Capital } \\
\text { Structure }\end{array}$ & Position & $\begin{array}{l}\text { Total } \\
\text { Experience } \\
\text { (Years) } \\
\end{array}$ & $\begin{array}{l}\text { Experience In } \\
\text { The Company }\end{array}$ & $\begin{array}{l}\text { Duration of } \\
\text { Telecommuting }\end{array}$ \\
\hline R1 & Telecommuter & Domestic & Company Manager & 22 & 14 Years & 3 Years \\
\hline $\mathbf{R 2}$ & Telecommuter & Domestic & Construction Draftsman & 20 & 14 Years & 3,25 Years \\
\hline $\mathbf{R 3}$ & Telecommuter & Domestic & IT System Manager & 23 & 14 Years & 2,16 Years \\
\hline R4 & Telecommuter & Domestic & Sales Officer & 13 & 2 Years & 9 Months \\
\hline $\mathbf{R 5}$ & Telecommuter & Foreign & Product Sales Manager & 20 & 11,16 Years & 11,16 Years \\
\hline R6 & Telecommuter & Domestic & Purchasing Chief & 7,25 & 6,25 Years & 6 Months \\
\hline $\mathbf{R 7}$ & Telecommuter & Foreign & Sales Manager & 12 & 6,25 Years & 3 Years \\
\hline $\mathbf{R 8}$ & Telecommuter & Foreign & Digital Marketing Mngr. & 8,75 & 4,16 Years & 4,16 Years \\
\hline R9 & Telecommuter & Foreign & Sales Representative & 14 & 7,5 Years & 6,5 Years \\
\hline R10 & Telecommuter & Foreign & Sales Representative & 13 & 6,5 Years & 6,5 Years \\
\hline R11 & Telecommuter & Foreign & Sales Representative & 20,5 & 5,83 Years & 5,83 Years \\
\hline R12 & Telecommuter & Foreign & Marketing Manager & 28,5 & 24,08 Years & 7,5 Years \\
\hline R13 & Telecommuter & Domestic & Authorization Manager & 15 & 7 Years & 5 Months \\
\hline R14 & Telecommuter & Domestic & Project Manager & 24 & 6 Months & 3 Months \\
\hline R15 & Telecommuter & Foreign & Sales Representative & 15,8 & 7,25 Years & 3,08 Years \\
\hline R16 & Telecommuter & Foreign & Authorization Officer & 3,5 & 3,5 Years & 1,5 Years \\
\hline R17 & Office Worker & Domestic & Spare Part Sales Mngr. & 21 & 1 Year & - \\
\hline R18 & Office Worker & Domestic & Marketing Product Mngr. & 21,85 & 2,5 Years & - \\
\hline R19 & Office Worker & Domestic & Planning Manager & 15 & 7 Years & - \\
\hline $\mathbf{R 2 0}$ & Office Worker & Domestic & After Sales Manager & 14 & 9 Months & - \\
\hline $\mathbf{R 2 1}$ & Office Worker & Domestic & Purchasing Manager & 29,25 & 8 Years & - \\
\hline
\end{tabular}

The length of the interviews, varied between 42,1 minutes and 83,47 minutes. During the interview, for the generally answered questions, it was drilled down by the opening questions in case of poor responses and it was provided to get satisfying answers by switching to other questions and asking in a different way in the following time. In this wise, by the mean of 63,19 minutes interview time, achieving rich data was provided. 
Table 3 Selected in-depth interview questions with teleworkers

- How was the shift into telecommuting carried out? How is this work order applied? Is there a chance that all employees prefer this work order? If not, what are the main criteria to be elected as a telecommuter?

- Are you satisfied with the way of telecommuting? If you are satisfied, can you describe the satisfactory aspects?

- Do you want to continue working in this way? If so, for how long? Can you explain the reasons?

- Did telecommuting increase your work satisfaction? If yes, why and how? If no, why and how?

- Does your manager support you in this process? If he/she supports, how?

- Are there any new methods applied for you in order to ease the telecommuting process and to the support this new way of working?

- Do you think that the current applications \& practices of the human resources management support telecommuting?

- What kind of developments do you find necessary for your current human resources management system?

- Did you receive a training regarding this process before telecommuting? If yes, what were the subjects of this training? Was this training sufficient for you? Do you have any constructive suggestions for the training management process, if so, what are they?

- How do you consider the process of telecommuting in terms of your career?

- Do you have any suggestions for the development of telecommunication work order? If you have suggestions, can you explain in detail?

- What should be done in order to enhance the success of the process and employee satisfaction in telecommuting?

\section{DATA ANALYSIS METHODS}

Grounded theory was applied. "It is a research design that is often employed when adequate theory is unavailable to explain a process or describe a concern of a group of subjects and how to resolve the issue or concern (Creswell, 2007)." (Witwer, 2013, p.43)

The survey of this qualitative research was conducted in Turkey. A semi-structured in-depth interview was used to collect the data in the light of the grounded theory approach. The interviews included both turkish teleworkers and non- teleworkers in order to see the expectations of teleworkers from HRM and non-teleworkers suggestions for HRM for teleworking process to be acceptable for them and this data gathering process enabled a reliability check between two groups. Until the saturation of the data was ensured, the interviews were carried on. "According to Creswell (1998), Using the constant comparative approach, the researcher attempts to saturate the categories - to look for instances that represent the category and to continue looking until the new information obtained does not further provide insight into the category" (Disbennett-Lee, 2005, p.54) So the sample size was determined according to the saturation of the data and the relations between the data. By the end of the 21 interviews, the data were saturated and the subjects started to repeat, so the interviews were completed. As the interviews continued, the active data analysis was also carried on. The qualitative analysis program "MAXQDA Analytics Pro" was used to anaylse and code the data. After each interview, the dialogues were transcripted and saved to the MAXQDA qualitative research software and continuously anaylsed upto saturation. 21 respondents were included in the scope of the study. 16 of the respondents were telecommuters, 5 of them were non-telecommuters. 
The data was analysed by open coding, axial coding and selective coding according to the process described by Strauss \& Corbin.

"The initial coding procedure, open coding, is defined as "the process of breaking down, examining, comparing, conceptualizing, and categorizing data" " (Strauss \& Corbin, 1990, p. 61). Data were fractured, and similar concepts were grouped into identifiable categories, with properties and dimensions. "Properties are the characteristics or attributes of a category. Dimensions represent locations of a property along a continuum" (Strauss \& Corbin, 1990, p. 69). (Stall-Meadows, 1998, p.28) So the study analysis was started with open coding in order to determine the grounded codes in the original raw data according to the systematic design of the grounded theory.

"Corbin and Strauss (2008) stated that open coding and axial coding often occur simultaneously, as researchers analyze data with the constant comparison method." (Gerst, 2012, p.141)

"In open coding the data is broken down into events, observations, and interactions. These data points are compared with others to identify common properties and categories. In axial coding, categories are related to sub-categories, and these relationships tested against the data (Corbin \& Strauss, 1990). Selective coding develops the relationships of the previously identified categories to a core category or a central phenomenon." (Leahy, 2012, p.47) As a result of the coding processes a theoretical model for "Expectations from human resources management" was developed. The results of selective coding showed two major themes: Expectations before the initiation and after the initiation of telecommuting.

\section{RESEARCH FINDINGS \& CONCLUSIONS}

Respondents' comments presented many execution suggestions about telecommuting for human resources management. Qualitative content analysis was processed for the texts based on the interviews and major themes were defined with constant comparison method. "A theme answers the question 'How?'. We consider a theme to be a thread of an underlying meaning through, condensed meaning units, codes or categories, on an interpretative level. A theme can be seen as an expression of the latent content of the text. Since all data have multiple meanings (Krippendorff, 1980; Downe-Wamboldt, 1992), themes are not necessarily mutually exclusive. A condensed meaning unit, a code or a category can fit into more than one theme. A theme can be constructed by sub-themes or divided into sub-themes." (Graneheim \& Lundman, 2004, p.107) Depending on this description of Graneheim \& Lundman, the texts were analysed and coded.

In the in-depth interviews hold with the purpose of defining the expections from human resources management for telecommuting, 19 main emphasized expectations and suggestions were reached after axial and selective coding. And mainly two major themes of expectations were generated: Expectations before the initiation of telecommuting and expectations after the initiation of telecommuting. Codes under the major themes were also defined as follows.

Table 4. The Major Category of Expectations From HRM \& Sub-categories, Codes and Frequency of Statements

\begin{tabular}{|l|l|l|}
\hline EXPECTATIONS FROM HUMAN RESOURCES MANAGEMENT & Frequency & $\mathbf{\%}$ \\
\hline Sub Categories \& Codes & $\mathbf{2 6}$ & $\mathbf{4 7 , 2 7 \%}$ \\
\hline Expectations Before The Initiation of Telecommuting & 8 & $14,55 \%$ \\
\hline Strong technical infrastructure necessity for telecommuting & 6 & $10,91 \%$ \\
\hline Training \& Orientation for the company processes & 6 & $10,91 \%$ \\
\hline Result oriented performance system & 3 & $5,45 \%$ \\
\hline $\begin{array}{l}\text { The contracts and job descriptions of the telecommuters should be defined and } \\
\text { necessary items should be added or additional protocol should be signed }\end{array}$ & 1 & $1,82 \%$ \\
\hline Signing a contract to ensure the information confidentiality in telecommuting & 1 & $1,82 \%$ \\
\hline The approppriate selection of the telecommuter & & 6 \\
\hline
\end{tabular}




\begin{tabular}{|l|l|l|} 
Shifting to telecommuting should be gradual & 1 & $1,82 \%$ \\
\hline Expectations After The Initiation of Telecommuting & $\mathbf{2 9}$ & $\mathbf{5 2 , 7 3 \%}$ \\
\hline Supporting expenses such as rent, electricity and so on & 6 & $10,91 \%$ \\
\hline Fusion meetings arrangements in terms of the culture of the organization & 4 & $7,27 \%$ \\
\hline Not skipping interim meetings for work coordination & 3 & $5,45 \%$ \\
\hline Occupational health \& safety should be cared & 3 & $5,45 \%$ \\
\hline Audit and control of the work environment at home & 3 & $5,45 \%$ \\
\hline $\begin{array}{l}\text { Human resources support for the telecommuter career and organization of necessary } \\
\text { trainings for the needed competencies }\end{array}$ & 3 & $5,45 \%$ \\
\hline Suggestions for partial telecommuting & 2 & $3,64 \%$ \\
\hline Interactive training arrangements when passing to new applications in the company & 1 & $1,82 \%$ \\
\hline Motivating the overtime works in telework or mobile work & 1 & $1,82 \%$ \\
\hline The telecommuter should not work if he has medical report & 1 & $1,82 \%$ \\
\hline The employee should be able to return to the workplace when the workload is higher & 1 & $1,82 \%$ \\
\hline There should be enough tables for the telecommuters when they arrive at the office & 1 & $1,82 \%$ \\
\hline Total (Valid) & $\mathbf{5 5}$ & $\mathbf{1 0 0 , 0 0 \%}$ \\
\hline
\end{tabular}

Within the scope of the study, 55 statements were found grounded in the data and the statements constituted the 19 codes listed above under the 2 major themes:

1. Expectations before the initiation of telecommuting

2. Expectations after the initiation of telecommuting

\subsection{EXPECTATIONS BEFORE THE INITIATION of TELECOMMUTING}

Nearly half of the comments of the respondents were about the expectations before the initiation of telecommuting. The most underlined codes were strong technical infrastructure necessity for telecommuting, training \& orientation for the company processes, result oriented performance system. These findings are coherent with the literature. The followings are the most representative statements chosen over the all comments under the related code to reflect and make feel the deep expectations of the telecommuters and non- telecommuters.

\subsubsection{Strong technical infrastructure necessity for telecommuting}

As noted by two teleworkers about "Strong technical infrastructure necessity for telecommuting" with the following comments,

\footnotetext{
"Telecommuting is quite out of question without technology. The infrastructure must be strong enough. Otherwise, it will be even impossible to understand whether the employee works or not." (R3)

- "For telecommuting, systematically more powerful hardware and more technological devices are needed. Advanced cameras and microphone systems can be provided for the telecommuter: systems providing simultaneous connection with the person you need to talk at any moment from home, touch operated and mobile systems should be used everywhere in the residence. I may say, I can talk to any of my collegue instantly online. For example, these systems should be mobile systems when I make coffee or wander around my house and should provide my independebility from the fixed screens and equipments but the continous view of the screens should exist with these systems.". (R14)
}

especially strong, powerful and advanced softwares and hardwares are expected by telecommuters. Another comment also underlines the inadequacy of the medium level for a successful telecommuting:

"Something should be done for reaching information and communication problems. Mobile meetings and teleconferences can be coordinated by skype. That wouldn't be a problem in 
today's world. But infrastructure of information technologies must be high-powered. Technology should be made the best of. The employer should provide these. Otherwise telecommuting will not be successful if you just telecommute in primitive conditions." (R19)

\subsubsection{Training \& Orientation for the company processes}

One of the most highlighted issues under the main theme of expectations before the initiation of telecommuting was the "Training \& Orientation for the company processes" which was one of the main expectations of the telecommuters. This is also underlined in literature. But with this study the appliers can see the problems experienced by the telecommuters and see the case from their eyes. Here are the comments reflecting both the positive and the negative experiences of the respondents:

- $\quad$ "Connecting to VPN, password of this password of that. We could not manage to learn using these for a while. If some kind of training had been provided, it would have been more comfortable. We figured out by trial-and-error. The training about the processes, programs could be provided during shifting process. Webex = Webinar" (R9)

- "Someone new is going to be hired. He is going to start as a telecommuter. He has been invited to Dubai. They taught him how to enter into the system. But mostly, he is being trained by his teammates and manager. It is good for him. But we did't have this chance." (R9)

- $\quad$ "The employee should be upgraded to the telecommuter competency level. He should know the work-flow and the system. I generally observe these incompetencies for salesmen. As they don't know the factory's workflow, they work disjointedly. But the people $l$ work with are also salesmen but they have worked in Germany for one month and received training and moreover they interned in the production line. The company made them control \& manage the production line and feel the job. The taught them how the work flows and then sent them to Turkey as salesmen. The employee is Turkish and the company is of German origin. They did not send the employee to Turkey to represent them as soon as they employed the person." (R18)

$\mathrm{R} 2, \mathrm{R} 5$ and R10 also underlined the same subject.

In sum, for these telecommuters training before starting telecommuting means a faster adaptation period for telecommuting. Besides, the concept of "telecommuter competency level" was reached through the dialogues of the respondents which was described as the level that the telecommuter is fully informed about the processes of the company and have a good command of the job. So the "telecommuter competency level" can be described by human resource management and the orientation program for telecommuters may be planned accordingly.

\subsubsection{Result oriented performance system}

Employers offer alternatives to increase flexibility for employees, such as compressed scheduling, flextime, and teleworking. The spectrum of workplace flexibility goes from "ad hoc flexibility" (i.e., as required by management) to "pure flexibility" (i.e., uses a "results-based" approach. One obstacle that exists is the "long-standing workplace norms," which is based on work hours and "'face time'". Subsequently, performance measurement in this setting would be based on hours rather than results. (Hurd, 2010, p.24) But on the contrary of these long-standing workplace norms, what was stated by the respondents as their expectation was a result oriented performance system which enables to get away from being tracked and monitored.

- "I heard about some applications where there is not any kind of debriefing, just ensuring if the responsibilities are completed is enough. But on the other hand, there is some kind of GPS tracking in some companies. I heard about interesting applications like this, where the people are monitored and under pressure." (R10)

- "In the end, the issue to be discussed is business result. If you can't see any improvement in the bottom line, it doesn't matter if someone is telecommuting or working in the office.

"Expecting the result is important. Result oriented." (R9, R5)

"To achieve success, performance system should be different too. In $x$ company sales assessment is carried out twice a month." (R17) 
In sum these teleworkers expect result oriented performance system which means for them trust and relieving from being monitored and from the feeling of pressure.

\subsubsection{The contracts and job descriptions of the telecommuters should be defined and necessary items should be added or additional protocol should be signed}

The respondent 10 underlined the importance of a contract specially defining the necessary items for the teleworker.

- "They did not sign any specific contract with me about telecommuting. It was a basic contract but had one or two items about telecommuting."

- "My transportation costs were covered. But they asked me to sign an additional protocol at that time, saying that I would repay the costs if I left within 6 months or 1 year. Because there's a possibility of moving and quitting 3 days later."

- $\quad$ "It was described as a part of the job description not in my old company but in my current company. It was signed."

Teleworking is a new way of working, so the job descriptions should be defined strictly by HRM and besides sufficient attention should be paid for the detailed contacts defining the working conditions of teleworking.

\subsubsection{Signing a contract to ensure the information confidentiality in telecommuting}

One of the suggestions emphasized by the respondent 3 is the ensurement of the information confidentiality.

"I have signed a contract about confidentiality. I think ensuring the information confidentiality in telecommuting is important. Sometimes I see the informations that is not known even by the boss. '(R3)

Before the adaptation of teleworking, for the sake of security, ensuring information confidentiality also by a specified contract is suggested as a check point for HRM.

\subsubsection{The approppriate selection of the telecommuter}

One of the points underlined by the respondent 17, a non- telecommuter and a manager, is the assessment of the employee's appropriateness for teleworking.

"The employees who are not suitable should be addressed to other jobs if possible. They should not be too relaxed." (R17)

For an effective teleworking system, especially at the first stages of the application, appropriateness assessment by frequent intervals can be suggested for HRM, so as to understand the adaptation and coping potential of the employee for teleworking conditions and challenges.

\subsubsection{Shifting to telecommuting should be gradual}

The respondent 17 considered the gradual shift to telecommuting as a key to adaptation and underlined the necessity of elucidating the new work arrangement.

- "If we shift to telework, the shifting process may be gradual. 15 days home, 15 days office or 2-3 days in a week. But regional sales groups stay as they begin, can not be shifted. You should tell people the system. How the new work arrangement will be, reporting necessity and what is expected should be told elaborately." (R17)

So in order to provide a successful telecommuting work arrangement, at first an incremental shift and observation of satisfaction may be appropriate and this may prevent the risk of abandonment of the new work arrangement by both the management and the employees. 


\subsection{EXPECTATIONS AFTER THE INITIATION of TELECOMMUTING}

\subsubsection{Supporting expenses such as rent, electricity and so on}

5 out of 21 respondents indicated the importance of expenses support with the 4 differing statement examples below:

- "In some countries they support the rent. For example, you spend extra electricity and natural gas. You may need a separate room. If your apartment is $1+1$, you may rent an apartment for 2000 TL instead of 1500 TL. This support could be motivating." (R7)

- $\quad$ "Sometimes I hear about some bad examples of telecommuting. I mean sometimes even the benefits are not provided, but telecommuting continues. We had all kinds of benefits provided. Printer, adsl, telephone, fax, office furniture, lunch, computer, etc." (R10)

- "In our time, only stationary telephone, internet, cell phone and ADSL expenses used to be covered by the company. Later, the company started to cover also the office supplies at home. Furniture, paper etc. were started to be covered by the company after a while when I left the company." (R7)

"But I cover the internet expenses myself. The "ticket" for my lunch is still being provided. At the end, I am at home. I don't eat much at noons, and I don't go out very often but my ticket benefit remains the same." (R13)

Sometimes telecommuters may have to bear the expenses of this working arrangement. But this case is identified as the "bad examples of telecommuting" which shall be get as a suggestion and an expectation of the telecommuters by the human resources management.

\subsubsection{Fusion meetings arrangements in terms of the culture of the organization}

According to the statements of the respondents in order to make the telecommuters feel the company culture deeply, fusion meetings arrangements are needed. One of the notable emphasis about the subject is the risk of drifting apart from the company by the declining commitment which is noted by the startling statement of "The name of the company, A company or B company, may not be much of an importance for the employee. Loneliness may lead someone to this." The details of the respondents' taughts, experiences and expectations are noted by the following statements:

- $\quad$ "HR may support teleworkers in terms of corporate culture by gathering them together, training and encouraging them for teamwork. People who interact as telecommuters all the time may lose their sense of being a team. They can arrange organizations. They should feel they are a team. Telecommuting employees may fall apart when they are used to telecommuting. These kind of organizations may be made for these people to feel the culture of the company." (R18)

- "One can think like I am here at this company today, tomorrow I may be in another company. That's because he/she is by the computer. May not have any sense of belonging. The name of the company, A company or B company, may not be much of an importance for the employee. Loneliness may lead someone to this. However, being embraced and called, being felt that he is a part of the company is necessary for them. An employee who always telecommutes should be called by company and should be provided with the opportunities of meetings and hanging out together. Even if the person is a telecommuter he shouldn't be away from work all the time. To me, a full time telecommuter is at a risk of drifting apart from work." (R21)

- $\quad$ "I think it would be better if we maintained the communication with each other to deepen the company commitment or to report and to make things better about both the companies' expectations and mine, at least with your country manager or about different expectations. But we don't have this kind of a system. Maybe we should take a step as to develop an environment where ideas are shared, more discussions are made and where there are satisfaction forms and complaint forms in every 6 months." (R8)

- "The strategies, and expansion of the mission and vision can be insufficient in terms of the people dealing with telecommuting for a long time. They may know about the mission but in order to create something cultural, there are things to be gathered. Their commitments may not be deep. They may break off, if not integrated with culture. They can not be fully adaptable, commitment to the company may not be enough, if not fully joined to the specific culture, it may break off easily. " (R18) 
One of the prominent suggestions of the respondents can be seen by "we should take a step as to develop an environment where ideas are shared, more discussions are made and where there are satisfaction forms and complaint forms in every 6 months", a statement which can be used as a best practice sample for the HR managers. At the first phase of employment suchlike applications are adopted but when the company shifts to a new work arrangement that can be thought as a first phase likewise. After the introduction of telecommuting, a satisfaction survey can be applied for telecommuters.

\subsubsection{Not skipping interim meetings for work coordination}

3 out of 21 respondents considered interim meetings as a must for a successful work coordination both for synergy and exchange of ideas for solution and for the road map they would follow. In this context the remarks of the respondents are as follows:

- "We used to meet on Skype twice a week, one of our friend coordinated the meeting, I was invited to the conference, our friends in Istanbul and Antalya used to be invited. Locations were different but the subjects were common. It was clear what the problems were, what we missed, what was happening in the factory and what was going to affect us. It was possible to observe which things we should do better. For this reason, these kinds of news and cases being informed in that meeting was important. Our friend, the coordinator, quitted and we have lost this coordination. What are we going to do for next? What is happening? These became to be missing. The same for telecommuting. When you telework, you should know the steps to follow, your purposes, how many of them you have reached or how many goals you have to reach to find a solution and this will also solve the discipline problems and motivational issues. It is possible if the people are business success oriented. They will know how to reach to success." (R18)

- "We gather to discuss certain issues face to face and to bring synergy. We go for two or three days. If there is training, we bring the training together with the works we should do and with the meetings to be held in Sweden." (R15)

- "Telecommuters get lonely at home. There may not be an interaction. It may have negative effects in terms of motivation. Synergy cannot be achieved. Ideas cannot be shared quickly without gathering. It may work in sales, marketing and routine jobs. But in my opinion, it doesn't work in research and development function. The follow-up system should also be different. To succeed, performance system should be different too. In X company sales assessment is carried out twice a month. Telecommuting cannot continue all the time, sometimes meetings should be held according to the importance of the work." (R17)

Respondent 17 especially emphasized the differing level of idea sharing need for different positions with "Ideas cannot be shared quickly without gathering. It may work in sales, marketing and routine jobs. But in my opinion, it doesn't work in research and development function." statement which gives the managers a clue about the terms and frequency of interim meetings for differing positions of telecommuting. For the companies applying teleworking, a tool describing the frequency of interim meetings can be prepared according to the positions and presented to the leaders as a guidance.

\subsubsection{Occupational health \& safety should be cared}

The respondents also noted that occupational health \& safety should be cared for telecommuters as well. When analyzed in detail these remarks are standing out:

\footnotetext{
"The furniture was selected as ergonomic and qualified." (R10)

"There were also guidelines for the security at work. Normally most of the companies do not have that. There were also programs about the personal home security. For example, how to deal with a possible fire sourcing from the stove at home. They get you a fire extinguisher. My company used to provide that." (R10)

- "We had also trainings about the occupational health \& safety during the year. They used to supply handouts. A content, presentation, video and related stickers are supplied. You need to stick them to some place. This ensures awareness at home. We had the chance to enhance the security at home." (R10)
} 
So respondents expect to be leaded by HRM about the occupational health \& safety risks and expects trainings, guidances and different awakening materials.

\subsubsection{Audit and control of the work environment at home}

For telecommuters audit of the work environment is also underlined by the following statements.

- $\quad$ "We were supported and asked if we had a work environment at home. My manager tried to make sure if the conditions were proper. At first he was a controller. Now he is focused on the result." (R9)

- $\quad$ "For all of these people, identical set of mobile internet connection, modem for home, cell phones, an investment of 1000 -1500 TL for one occasion in order for them to build an office at home, notebooks, colored printers were provided, making it possible to carry them in a tiny luggage, to make agreements right away. Then we told them it is not necessary for them to come to the office anymore." (R12)

Respondent 9, a telecommuter, indicated the importance given for the proper working conditions of the working environment and often controls made in the first phase of telecommuting which stands as a good example that can be taken from the lively experience of the respondent.

\subsubsection{Human resources support for the telecommuter career and organization of necessary trainings for the needed competencies}

3 out of 21 respondents expressed their desperation about their career due to the decreasing visibility and lack of involvement for developing the competencies needed for their career.

\footnotetext{
"They appointed a regional human resources manager for all of us. If someone telecommutes, he is mostly working from a small office, since the office is small, he does not have much chance regarding career. HR does not do many things for career. Different competencies may be taught. They applied role play for me in webex. They told me to "go into the library, pretend if I was doing that job and facilitate the dispute". But I could not succeed. HR never supported me about career. If they had done something to improve this skill, I wouldn't have been that much ashamed. Then they suddenly informed me that they will not be able to go ahead in my career for this position." (R9)

- "Once you want to return and demand high positions in the office, it becomes a "out of sight, out of mind" case. I am a global senior manager but when you say you want to be a local senior manager and take a step in your career, I am a man they have never met, but the other candidate is always with them, coming and going to the office and is preferred." (R12)

- "In a short time when you shift to telework, your visibility decreases. I may have lived this. You are only in touch with the people related with your job. The possibility to be in touch with the other people disappears for a teleworker. What does it mean? In terms career opportunities decreasing visibility is a problem. While it is possible to have good relationships with the other departments, you are only in touch with whom is related with your job. Sometimes there are some people you even do not recognize, these are teleworkers. It effects career. Even I had worked in the office before, since I am in the global organization, I have lost the job opportunities in the local organization. Due to the isolation."(R10)
}

"In a short time when you shift to telework, your visibility decreases. ...... Even I had worked in the office before, since I am in the global organization, I have lost the job opportunities in the local organization. Due to the isolation." was one of the most striking statement about the effect of isolation on the career. So this experience shows that even experienced in the office, a teleworker's promotion chance is lower.

So at this point, HR support is expected both by trainings and by organization arrangements providing visibility. 


\subsubsection{Suggestions for partial telecommuting}

In the study the respondents suggested a more flexible model of telecommuting enabling partial teleworking in order to prevent the breakaway from the company.

- $\quad$ "My personal opinion is that a more flexible model where one can both telecommute and work at office may be developed. A model as to being at the office for 1-2 days would be more effective." (R7)

- "An employee who always telecommutes should be called by company and should be provided the opportunities of meetings and hanging out together. Even if the person is a telecommuter, he shouldn't be away from work all the time. I think there is a risk of breakaway from work for a full-time telecommuter." (R21)

In accordance with the suggestions of the respondents, rather than full-time teleworking, partial teleworking can be preferred to avoid from the loss of commitment and motivation decrease.

\subsubsection{Interactive training arrangements when passing to new applications in the company}

One of the expectations emphasized by the teleworkers is the interactive training arrangements for new applications depending on their experiences and the hardships encountered.

"We have put a system about CRM into practice. A training was provided but it's not understood at the first stage. It may be comprehended in office by asking about but it may get difficult at home. An interactive training should have been organized." (R7)

For teleworkers interactive trainings meant the possibility to ask questions and make practices and adaptation for new applications as quick as the office workers. So for the appliers this presents a fact extracted from the lively experiences that should not be ignored.

\subsubsection{Motivating the overtime works in telework or mobile work}

Respondent 7 emphasized that a telecommuter is more open to overtime work at home and complained about spending more energy. Correspondingly, the expectation is to be motivated for the overtime work.

"If you are a telecommuter, you don't work from 08.00 to 17.30. You are open to work at home 24 hours. You spend more energy. You go to dinner with the dealer. In fact, this is a kind of overtime work. Something motivating may be done about this. " (R7)

At this point, there is a contradiction with the general acceptance that telecommuting gives chance for work-life balance. So the underlying message from this experience is for the leaders so as to observe and be in touch with the teleworker and if there is overtime work, this should be also compensated either by free-time or payment just like the office worker.

\subsubsection{The telecommuter should not work if he has medical report}

Respondent 3 stated that as an employee even in morbidity, he worked remotely.

"I telework even if I am sick. There was a time when I solved a problem even if I had $41^{\circ} \mathrm{C}$ fever and was in the hospital." (R3)

This experience is also an indicator that there are primary points that is being ignored for teleworkers. So it will be appropriate to underline equal execution for both teleworkers and office workers in case of illness.

\subsubsection{The employee should be able to return to the workplace when the workload} is higher

Respondent 10's statement below gives a significant feedback about the status of excessive busyness of the teleworker.

"The opposite might be possible if you are working in a very busy position, if you travel a lot. I requested working in the office when I was at x company. If the workload is too much, 
the commitment decreases. If the workload is too much, home office working will not increase your commitment." (R10)

So it can be suggested for the leaders to make the return to the office possible in case of extra workload or upon the request of the teleworker.

\title{
7.2.12. There should be enough tables for the telecommuters when they arrive at the office
}

In the study the respondent 10 suggested that enough number of tables should be reserved in the office for telecommuters in the case for office work. This is also a precious feedback from the experiences of a teleworker that may lead for best practices for human resources management and the other managers.

\begin{abstract}
"For the telecommuters, there should be 3-4 tables in order to use when they are in the office. We had small meeting rooms, single rooms. These rooms are soundproof, like small home offices. But they are very limited. You need to search for available places and make reservations in advance. If there are at least 4 tables for the teleworkers coming to the office, it would be better. Otherwise you have to search for available seats. You have to check if your collegue is coming or not. If not, you may sit on his seat. It is hard trying to find some place to sit in this way." (R10)
\end{abstract}

\section{DISCUSSION}

There were not many generalizations provided in this study but if, in a company, the shift to telecommuting is unsuccessful at first, the probability to adapt this new work arrangement again will be rather difficult. So the goal was to present suggestions and expectations of the telecommuters for HRM depending on the experiences and challenges of telecommuters so as to frame a clear plan for managers showing the points to be cared both before and after the shifting period.

In this respect, it will be appropriate to suggest implementers a gradual shift from a partial teleworking to full-time teleworking and a telecommuter satisfaction survey in certain periods after the implementation.

Strong technological infrastructure is emphasized as a must in order to prevent the lack of communication between the teleworker and the other colleagues and managers. At this point, the importance of retrieving data from the same database with certain softwares, instant messaging and mobile application usage providing simultaneous connection may be underlined. Besides; the training of these softwares should be arranged and hardwares with the required capacity should be provided for teleworkers before shifting to the teleworking system.

Another pinpointed expectation before teleworking adaptation is the need of training and orientation for the company processes in order to reach the "Telecommuter Competency Level" which is a concept defined based on the comments of the respondents and is not encountered in the literature before. This new defined concept according to the definitions of the respondents means that the teleworker should be fully informed about the processes of the company.

The result of decreasing commitment of teleworkers with a heavy work load is deduced from the study. And in this case instead of fulltime teleworking, a partial teleworking arrangement is suggested for the human resources managers. And if a fulltime teleworking is indispensable, more frequent communication is posited.

Due to the lack of visibility and human resources insufficient career support for teleworkers, teleworking is found to affect the career mainly in a negative way according to results of the study.

In the adaptation period of teleworking, the human resources functions and processes should be redesigned strategically for teleworking considering the suggestions and expectations uncovered in the findings section. For this new way of working, besides the telecommuters, also the top management, human resources management and the leaders are in the position to take on the responsibility. On the side of human resources management it is crutial to restructure the recruitment process, orientation programme, training arrangements and technical support processes according to the way of telework taking into consideration the communication processes, commitment and motivation of teleworkers, the possible stressful cases and mutual trust between the teleworker and the management. 


\section{CONCLUSION}

The data generated from the in-depth interviews were theoretically framed by grounded theory and the findings of the research are generally coherent with the literature. The reflected experiences, feelings and the struggles of the telecommuters are remarkable examples that are able to explain the meaning of the numerical results of the quantitative researches about telecommuting so as to shed light to the feelings and struggles of telecommuters. The striking examples of the telecommuters' experiences lived, given in the findings section of the article, are the main contributions of the study. In accordance with the findings, suggestions are presented for the for human resource managers and the other managers.

\section{LIMITATION}

There are three main limitations of the study. The first limitation is that the study cannot be generalized as it is a qualitative study. But in order to provide transferability, thick descriptions of the respondents and observed processes are made.

Secondly, it was assumed in the study that the respondents comprehended the questions and statements used in the questionnaire in the same way and expressed their experiences as is and reflected just what they felt in fact.

Snowball sampling method was used for the respondents' selection. It is requested from the respondents to suggest one of their telecommuting colleagues or friends to participate in the survey and besides the respondents were also acknowledged about the importance of not sharing their ideas about the subject of the survey with their reference. But the impossibility of controlling this situation stands as the third limitation of the study.

Acknowledgement/Bilgilendirme: This article is reproduced from the thesis "A Qualitative Research Surveying the Effect of Telework on Working Life in Turkey" prepared under the Supervision of Prof. Dr. Ayșe Oya Özçelik and accepted by Institute of Social Sciences of Istanbul University in 2018.

\section{REFERENCES}

Coenen, M., Kok, R.A.W. (2014). Workplace flexibility and new product development performance: The role of telework and flexible work schedules. European Management Journal, 32, 564 576.

Disbennett-Lee, R. (2005). A study of international life coaches on the skills and strategies used during the coaching process. Unpublished PhD Thesis. Retriewed from ProQuest Dissertations and Theses (UMI No. 3183531) on June 1, 2019.

Gerst, S. (2012). The co-teaching journey: A systematic grounded theory study investigating how secondary school teachers resolve challenges in co-teaching Unpublished $\mathrm{PhD}$ Thesis. Retriewed from ProQuest Dissertations and Theses (UMI No. 3517723) on June 1, 2019.

Graneheim,U.H., Lundman, B. (2004). Qualitative Content Analysis in nursing research: concepts, prosedures and measures to achieve trustworthiness. Nurse Education Today, 24, 105-112.

Hurd, D.A. (2010). Comparing teleworker performance, satisfaction and retention in the joint interoperability test command. Unpublished $\mathrm{PhD}$ Thesis. Retriewed from ProQuest Dissertations and Theses (UMI No. 3420039) on June 1, 2019.

Keating, E., Broek, D.V.D. (2007). Australia. Blanpain, R. (Ed.). European framework agreements and telework: Law and practice. In A European and comparative study (p. 79). The Netherlands: Kluwer Law International.

Leahy, K. B. (2012). The making of a CIO: A grounded theory study of professional development of information technology executives. Unpublished $\mathrm{PhD}$ Thesis. Retriewed from ProQuest Dissertations and Theses (UMI No. 3551093) on June 1, 2019.

Long, D. J. (2008). What should I eat next? Development of a theoretical model of how college-aged 
football players make food choices. Unpublished PhD Thesis. ProQuest Dissertations and Theses (UMI No. 3330678) on June 1, 2019.

Martin, B.H., MacDonnell, R. (2012). Is telework effective for organizations? Management Research Review, 35, 602-616.

Polit, D.F., Beck, C. T. (2010). Generalization in quantitative and qualitative research: Myths and strategies. International Journal of Nursing Studies, 47, 1451-1458.

Polit, D. F., Beck, C. T. (2012). Nursing research: Generating and assessing evidence for nursing practice. China: Wolters Kluwer, Lippincott Williams \& Wilins.

Potts, E. A. (2006). Telework and perception of management behavioral effectiveness within the information technology industry. Unpublished $\mathrm{PhD}$ Thesis. Retriewed from ProQuest Dissertations and Theses (UMI No. 3226234) on June 1, 2019.

Rubin, A. (2008). Practitioner's Guide to Using Research for Evidence-Based Practice. New Jersey: John Wiley \& Sons, Inc., ProQuest Ebook Central, http://ebookcentral.proquest.com/lib/gelisim/detail.action?docID=353396.

Stall-Meadows, C. E. (1998). Grounded meta-analysis of qualitative case study dissertations in distance education pedagogy. Unpublished $\mathrm{PhD}$ Thesis. Retriewed from ProQuest Dissertations and Theses (UMI No. 9918818) on June 1, 2019.

Witwer, S. M. (2013). An in-depth exploration of successful weight loss management. Unpublished $\mathrm{PhD}$ Thesis. Retriewed from ProQuest Dissertations and Theses (UMI No. 3606019) on June 1, 2019. 